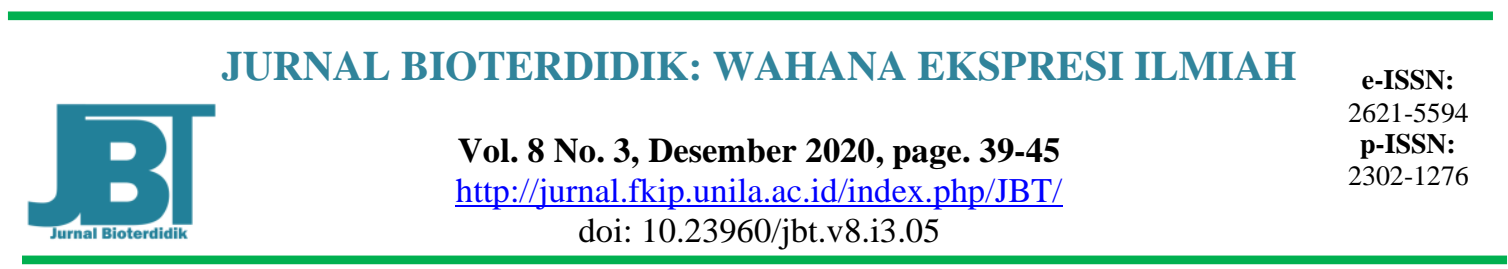

\title{
Analisis Kemampuan Berpikir Tingkat Tinggi Peserta Didik pada Materi Perubahan Lingkungan di SMA Negeri 1 Gadingrejo
}

\author{
Yesica Renita Putri, Darlen Sikumbang, Ismi Rakhmawati \\ Pendidikan Biologi, Fakultas Keguruan dan Ilmu Pendidikan, Universitas Lampung, Jl. Prof. Dr. \\ Soemantri Brojonegoro No. 1 Bandar Lampung, Indonesia \\ email: yesicaarenita28@gmail.com
}

\begin{abstract}
Analysis of high order thinking skills of students on environmental change material in SMA Negeri 1 Gadingrejo. This study aims to determine the high-level thinking skills of students of SMA Negeri 1 Gadingrejo class X on environmental change material. The design used in this research is descriptive with a quantitative approach. The research sample was students in class X IPA 1, X IPA 4 and X IPA 5 totaling 104 students who were selected by purposive sampling technique. Higher order thinking skills data with written tests and using the google form format. Higher thinking skills data were analyzed descriptively. The results showed that the higher order thinking skills of students at SMA Negeri 1 Gadingrejo were greatly reduced with an average percentage value of 53.52. So it can be concluded that the analysis of high-level thinking skills is still low with a very low category.
\end{abstract}

Keywords: analysis, environmental changes, higher order thinking skills

\begin{abstract}
Abstrak: Analisis kemampuan berpikir tingkat tinggi peserta didik pada materi perubahan lingkungan di SMA Negeri 1 Gadingrejo. Penelitian ini bertujuan untuk mengetahui kemampuan berpikir tingkat tinggi peserta didik SMA Negeri 1 Gadingrejo kelas X pada materi perubahan lingkungan. Desain yang digunakan dalam penelitian ini adalah deskriptif dengan pendekatan kuantitatif. Sampel penelitian adalah peserta didik kelas X IPA 1, X IPA 4 dan X IPA 5 berjumlah 104 peserta didik yang dipilih dengan teknik purposive sampling. Data kemampuan berpikir tingkat tinggi dilakukan menggunakan format google form. Data kemampuan berpikir tingkat tinggi dianalisis secara deskriptif. Hasil penelitian menunjukkan bahwa kemampuan berpikir tingkat tinggi peserta didik di SMA Negeri 1 Gadingrejo tergolong kurang sekali dengan ratarata nilai persen sebesar 53,52. Jadi dapat disimpulkan bahwa analisis kemampuan berpikir tingkat tinggi masih rendah dengan kategori kurang sekali.
\end{abstract}

Kata kunci: analisis, perubahan lingkungan, kemampuan berpikir tingkat tinggi 


\section{PENDAHULUAN}

Pada abad pengetahuan yaitu abad 21, manusia dituntut memiliki beberapa kemampuan yaitu kemampuan berpikir tingkat tinggi, kemampuan bekerja sama, kreatif, terampil, dan mempunyai kemampuan berkomunikasi serta mampu belajar sepanjang hayat (lifelong learning) (Annuuru, 2017). Dari beberapa tuntutan tersebut, berpikir tingkat tinggi merupakan salah satu kemampuan yang mestinya dapat dipahami oleh manusia. Dimana dalam proses pembentukan kemampuan berpikir tingkat tinggi dibutuhkan adanya pendidikan (Annuuru, 2017).

Kemampuan berpikir tingkat tinggi peserta didik di Indonesia masih tergolong rendah berdasarkan pencapaian prestasi sainsnya (Noma, 2016). Hal ini terbukti dari hasil indeks pembangunan pendidikan Indonesia berada pada peringkat ke-69 dari 127 dikarenakan lemahnyai proses pembelajaran di Indonesia yang kurang didorong untuk mengembangkan kermampuan berpikir (Permanasari, 2013).

Pencapaian prestasi sains yang tergolong rendah, disebabkan beberapa faktor antara lain, kebiasaan asesmen di Indonesia lebih berorientasi mengukur kemampuan berpikir tingkat rendah, pesertai didik belum dilatih secara optimal untuk mengembangkan kemampuan berpikir tingkat tinggi (Depdiknas, 2008). Hal tersebut juga menunjukkan pentingnya pendidik mengarahkan peserta didiknya untuk berpikir tingkat tinggi agar mampu bersaing dengan negara negara lain. Salah satu faktor yang menyebabkan kemampuan berpikirnya masih rendah adalah kurang terlatihnya anak Indonesia dalam menyelesaikan tes atau soal-soal yang sifatnya analisis, evaluasi, dan kreativitas. Soalsoal yang memiliki karakteristik tersebut i adalah soal-soal HOTS (Dewi, 2016).

Berdasarkan hasil wawancara kepada pendidik biologi kelas X SMA Negeri 1 Gadingrejo, diketahui bahwa proses pembelajaran masih berpusat pada guru (teacher centered) dan pendidik masih memberikan soal latihan maupun soal ujian yang didominasi oleh indikator berpikir tingkat rendah yaitu dengan $\mathrm{C} 1, \mathrm{C} 2$ dan C3. Meskipun indikator yang diterapkan masih sebatas C1, C2, dan C3 hasil belajar peserta didik masih banyak yang tidak mencapai Kriteria Ketuntasan Minimal (KKM) yang telah ditetapkan oleh sekolah yaitu 75. Hal ini dapat dibuktikan dari hasil rata-rata Penilaian Tengah Semester (PTS) peserta didik kelas X Tahun Pelajaran 2018/2019 untuk mata pelajaran biologi sebesar 65,75. Pencapaian nilai PTS peserta didik masih banyak yang di bawah KKM. Hal tersebut dikarenakan keterampilan berpikir tingkat tinggi peserta didik belum optimal sehingga keterampilan berpikir yang dimiliki peserta didik masih rendah.

Selain itu, berdasarkan hasil wawancara, peserta didik mengalami kesulitan dalam belajar biologi pada beberapa materi salah satunya yaitu materi menganalisis perubahan lingkungan. Padahal materi perubahan lingkungan merupakan salah satu materi yang membahas permasalahan yang sering terjadi pada kehidupan sehari-hari, namun pada kenyataannya dalam mempelajari materi perubahan lingkungan tersebut, nilai latihan soal dari beberapa peserta didik relatif rendah.

Di tengah pendemi Covid-19 saat ini, dunia pendidikan banyak mengalami perubahan. Perubahan tersebut menyebabkan pembelajaran jarak jauh menjadi pilihan utama, meskipun masih banyak kendala yang dialami baik oleh peserta didik maupun pendidik. Proses pembelajaran secara daring dilakukan dari rumah masing-masing peserta didik. Dengan adanya perubahan kegiatan pembelajaran melalui tatap muka disekolah berubah menjadi pembelajaran jarak jauh menuntut pendidik untuk ikut bertransformasi menggali kreativitasnya dalam menyampaikan materi pembelajaran dengan menggunakan media pembelajaran yang tersedia, seperti google class room yang menjadi salah satu media yang digunakan di SMAN 1 Gadingrejo. 
Tidak dapat dipungkiri adanya wabah Covid-19 menjadi permasalahan bagi peserta didik. Berdasarkan wawancara dengan peserta didik, ketika proses pembelajaran dilakukan secara daring masalah yang muncul adalah peserta didik mengalami kesulitan untuk melakukan konsultasi dengan pendidik terutama untuk materi yang dianggap membutuhkan penjelasan dan pemahaman yang lebih mendalam.

Beberapa penelitian yang terkait dengan penelitian ini yaitu penelitian (Angrain, 2019) menyatakan bahwa kemampuan berpikir tingkat tinggi siswa kelas $X$ tergolong pada kategori kurang sekali. Hal ini dikarenakan pembelajaran yang melibatkan kemampuan berpikir tingkat tinggi membutuhkan kejelasan komunikasi untuk mengurangi ambiguitas dan kebingungan serta meningkatkan sikap siswa dalam berpikir tentang tugas. Selain itu penelitian (Putri, 2018) menyimpulkan bahwa kemampuan berpikir tingkat tinggi peserta didik masih tergolong rendah. Hasil penelitian ini dapat dijadikan sebagai referensi dalam penelitian menganalisis kemampuan berpikir tingkat tinggi.

Berdasarkan uraian latar belakang tersebut, maka peneliti tertarik melakukan penelitian yang berjudul "Analisis Kemampuan Berpikir Tingkat Tinggi Peserta Didik pada Materi Perubahan Lingkungan di SMA Negeri 1 Gadingrejo".

\section{METODE}

Penelitian ini dilaksanakan pada bulan Mei semester genap tahun pelajaran 2019/2020 di SMA Negeri 1 Gadingrejo. Populasi dalam penelitian ini adalah seluruh peserta didik kelas X SMA Negeri 1 Gadingrejo tahun pelajaran 2019/2020 yang berjumlah 241 peserta didik yang terdiri atas 7 kelas (X IPA 1 - X IPA 7). Pengambilan sampel dalam penelitian ini menggunakan teknik purposive sampling yang bertujuan agar data yang diperoleh nantinya bisa lebih representatif (Sugiyono, 2012). Bila subjek kurang dari 100 lebih baik diambil semua, kemudian jika subjek lebih dari 100 dapat diambil antara $10-15 \%$ atau 20-25\% atau lebih (Arikunto, 2013). Jumlah sampel yang diambil dari penelitian adalah $40 \%$ dari 241 peserta didik, sehingga yang menjadi sampel dalam penelitian adalah 104 peserta didik dari jumlah populasi. Sampel penelitian ini diwakilkan oleh peserta didik kelas X IPA 1, X IPA 4, dan X IPA 5. Pada penelitian ini teknik analisis data yang digunakan yaitu dengan menilai jawaban peserta didik dengan memberikan skor 1 untuk jawaban benar dan memberikan skor 0 untuk jawaban yang salah. Selanjutnya, data skor kemampuan berpikir tingkat tinggi peserta didik dianalisis menggunakan Microsoft Exel kemudian dirata-ratakan.

Penelitian ini merupakan deskriptif dengan pendekatan kuantitatif. Prosedur penelitian dibagi menjadi tiga tahapan yaitu tahap prapenelitian, tahap pelaksanaan penelitian, dan tahap akhir. Tahap prapenelitian meliputi studi pendahuluan, pembuatan instrument penelitian serta menetapkan sampel penelitian. Tahap pelaksanaan, kegiatan yang dilakukan yaitu memberikan instrumen penelitian kepada peserta didik dengan format google form. Pada tahap akhir, kegiatan yang dilakukan adalah mengolah data tes kemampuan berpikir tingkat tinggi.

Data kemampuan berpikir tingkat tinggi dianalisis secara deskriptif. Sedangkan, uji instrumen kemampuan berpikir tingkat tinggi meliputi uji validitas, reliabilitas, daya beda, dan tingkat kesukaran menggunakan software Anates. 


\section{HASIL DAN PEMBAHASAN}

Penelitian yang dilakukan di SMA Negeri 1 Gadingrejo, diperoleh data mengenai kemampuan berpikir tingkat tinggi peserta didik kelas $\mathrm{X}$ pada materi perubahan lingkungan disajikan pada Tabel 1 berikut:

Tabel 1. Data kemampuan berpikir tingkat tinggi

\begin{tabular}{ccc}
\hline Kelas & $\begin{array}{c}\text { Nilai Persen (NP) Kemampuan } \\
\text { Berpikir Tingkat Tinggi } \\
\text { Peserta Didik (\%) }\end{array}$ & Kriteria \\
\hline X IPA 1 & 52,7 & Kurang Sekali \\
\hline X IPA 4 & 50 & Kurang Sekali \\
\hline X IPA 5 & 57,87 & Kurang \\
\hline $\begin{array}{c}\text { Rata-rata NP } \\
(\%)\end{array}$ & 53,52 & Kurang Sekali \\
\hline
\end{tabular}

Berdasarkan data kemampuan berpikir tingkat tinggi nilai rata-rata peserta didik sebesar 53,52\% dengan kategori kurang sekali. Rendahnya kemampuan berpikir tingkat tinggi peserta didik tersebut disebabkan beberapa faktor yang mempengaruhinya diantaranya yaitu kualitas proses pembelajaran dapat dilihat dari aktivitas belajar dan pemahaman peserta didik berdasarkan kompetensi dasar dan indikator yang harus dicapai. Haryati (2012) kualitas pembelajaran secara operasional dapat diartikan sebagai intensitas keterkaitan sistemik dan sinergis antara guru dan siswa serta media pembelajaran dalam menghasilkan proses dan hasil belajar yang optimal dengan tuntutan kulikuler. Hal ini sesuai dengan hasil wawancara peneliti dengan salah seorang pendidik biologi di SMA Negeri 1 Gadingrejo, bahwa aktivitas peserta didik mendengarkan pendidik mengajar dan mencatatnya serta media pembelajaran yang digunakan oleh pendidik adalah buku paket dan PPT, sehingga belum menciptakan suasana belajar yang aktif dan belum memfasilitasi proses interaksi antara peserta didik dan pendidik.

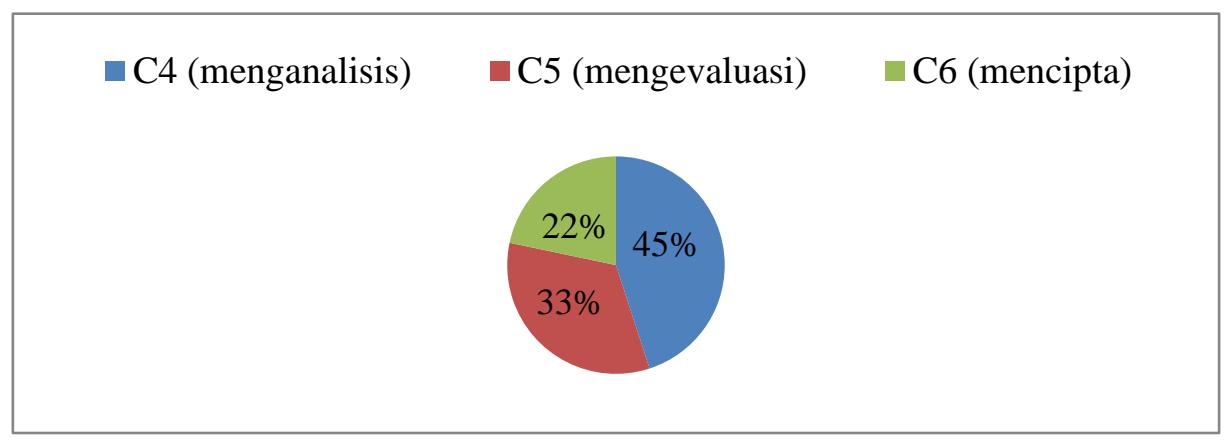

Gambar 1. Kemampuan berpikir tingkat tinggi dalam menjawab soal berdasarkan tingkat berpikir

Indikator kemampuan berpikir tingkat tinggi yang paling banyak dijawab peserta didik yaitu tingkat berpikir C4 (menganalisis) dengan persentase 45\% (Gambar 1). Terlihat pada hasil analisis peserta didik sudah mampu menjabarkan permasalahan dan mengarah pada penyelesaian masalah yang dimaksud soal. Hal ini sejalan dengan penelitian (Yulianis, 2019) menunjukkan bahwa tingkatan kognitif menganalisis lebih besar dibanding dengan tingkatan kognitif lainnya.Tingkat indikator C4 (menganalisis) 
juga merupakan tingkat termudah pada kemampuan berpikir tingkat tinggi dibanding dengan tingkat indikator lainnya.

Kemampuan peserta didik pada tingkat berpikir C4 (menganalisis) pada kategori cukup dipengaruhi oleh faktor kesempatan peserta didik untuk bertanya sebelum proses pembelajaran hal ini mengakibatkan peserta didik terbiasa menganalisis suatu pertanyaan, hal tersebut dipaparkan oleh pendidik saat wawancara dengan peneliti. Tingkat berpikir menganalisis adalah keterampilan menjabarkan materi kedalam bagian yang jelas.

Pada tingkat berpikir C5 (mengevaluasi) diperoleh persentase sebesar 33\% lebih sedikit dijawab oleh peserta didik. Rendahnya persentase peserta didik dalam mengerjakan soal C5 (mengevaluasi) karena peserta didik merasa sulit untuk menghubungkan fakta soal dengan konsep pembelajaran, memeriksa dan menilai pilihan jawaban yang homogen. Soal yang disediakan menunjukkan bahwa peserta didik dituntut mampu menilai dan memutuskan analisis terhadap permintaan soal. Hal ini sesuai dengan pendapat (Yulianis, 2019) tingkatan kongnitif mengevaluasi diperoleh sebesar 29 beradapada kategori kurang baik. Tingkat berpikir C5 (mengevaluasi) lebih rendah dari tingkat berpikir C4 (menganalisis) karena tidak semua peserta didik mampu memutuskan masalah, menilai masalah, mendukung ataupun menolak serta memprediksi permasalahan dengan tepat. Tingkat berpikir C5 (mengevaluasi) adalah memberi penilaian pada suatu pendapat, solusi, masalah dan menggunakan kategori yang sesuai dalam memastikan manfaatnya.

Pada tingkat berpikir C6 (mencipta) diperoleh persentase sebesar 22\% lebih sedikit dijawab peserta didik dibandingkan dengan tingkat berpikir lainnya. Rendahnya persentase peserta didik dalam mengerjakan soal C6 (mencipta) karena peserta didik kurang mampu memahami permasalahan yang terjadi pada soal dan peserta didik terkecoh oleh pilihan jawaban yang homogen. Hal ini sejalan dengan penelitian (Fazira, 2019) bahwa soal dengan tingkat kognitif C6 (mencipta) tergolong kedalam kategori rendah. Rendahnya kemampuan mencipta peserta didik dipengaruhi oleh kebiasaan peserta didik yang hanya mengerjakan soal yang berada pada buku teks. Tingkat kognitif mencipta adalah kemampuan untuk merancang tahapantahapan dalam menyelesaikan masalah tertentu serta memberikan alasan yang tepat. Silitonga (2018) kemampuan mencipta dapat dilatih dengan membiasakan mengerjakan permasalahan dalam LKS dan penerapan model pembelajaran berbasis Problem Based Learning.

Tabel 2. Persentase peserta didik menjawab benar berdasarkan subtopik Sub-topik Peresentase (\%)

\begin{tabular}{ll}
\hline Dampak perubahan lingkungan & $50 \%$ \\
\hline Penanggulangan & $52 \%$ \\
\hline Penyebab perubahan lingkungan & $51 \%$ \\
\hline Data perubahan lingkungan & $62 \%$ \\
\hline
\end{tabular}

Hasil analisis pada Tabel 2 diketahui bahwa dari 104 peserta didik yang bisa menjawab benar pada subtopik data perubahan lingkungan sebanyak $62 \%$ peserta didik. Jumlah peserta didik yang menjawab benar pada subtopik data perubahan lingkungan lebih tinggi dibandingkan dengan sub-topik lainnya. Soal dengan subtopik data perubahan lingkungan didominasi oleh indikator C4 (menganalisis) sehingga rata-rata peserta didik dapat menjawab dengan benar dan subtopik data perubahan lingkungan mudah dipahami sehingga mudah dicerna oleh peserta didik. Hal ini sesuai dengan pendapat (Yuliati, 2015) menyebutkan bahwa data perubahan lingkungan sangat dekat 
dengan kehidupan sehari-hari serta tingginya kepedulian terhadap lingkungan, maka peserta didik dengan mudah menjawab soal tersebut.

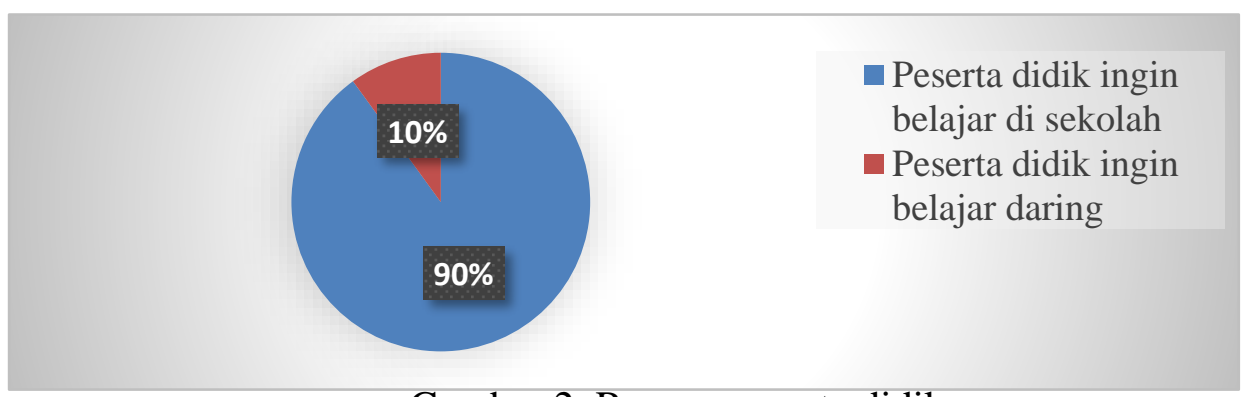

Gambar 2. Respon peserta didik

Pada Gambar 2 dapat diketahui bahwa respon peserta didik ingin belajar di sekolah lebih banyak dibandingkan dengan respon peserta didik ingin belajar daring. Hasil wawancara dengan peserta didik melalui google form, $90 \%$ peserta didik lebih memilih bertatap muka dengan pendidik lebih efektif daripada belajar pembelajaran jarak jauh karena alasan terkendala fasilitas dan biaya serta kurangnya interaksi kelas. Walaupun peserta didik mendapatkan kuota belajar gratis $5 \mathrm{gb}$, kuota belajar tersebut tidak cukup untuk kebutuhan selama proses pembelajaran daring. Kemudian $10 \%$ peserta didik memilih belajar di rumah (daring).

\section{SIMPULAN}

Berdasarkan hasil pembahasan maka dapat disimpulkan bahwa kemampuan berpikir tingkat tinggi peserta didik pada materi perubahan lingkungan kelas X SMA Negeri 1 Gadingrejo tergolong dalam kategori kurang sekali, hal ini ditunjukkan dari hasil penelitian yang didapatkan yaitu rata-rata nilai persen sebesar 53,52.

\section{DAFTAR RUJUKAN}

Angraini, Gustia., Sriyati, Siti. (2019). Analisis Kemampuan Berpikir Tingkat Tinggi Siswa SMAN Kelas X di Kota Solok pada Konten Biologi. Jurnal of Education Informatic Technology aand Science, 1(1). 114-124.

Arikunto. (2013). Evaluasi Program Pendidikan Edisi Kedua. Jakarta: BumiAksara.

Annuuru, Tia Agusti., Johan, Riche Cynthia., dan Ali, Mohammad. (2017). Peningkatan

Kemampuan Berpikir Tingkat Tinggi dalam Pelajaran Ilmu Pengetahuan Alam

Peserta Didik Sekolah Dasar melalui Model Pembelajaran Treffinger. Jurnal Edutcehnologia, 3(2).136-144.

Depdiknas. (2008). Strategi Pembelajaran Matematika dan Ilmu Pengetahuan Alam

Direktorat Jendral Peningkatan Mutu Pendidikdan Tenaga Kependidikan. Jakarta:

Departemen Pendidikan Nasional.

Dewi, Nastitisari., Riandi. (2016). Analisis Kemampuan Berpikir Kompleks Siswa Melalui Pembelajaran Berbasis Masalah Berbantuan Mind Mapping. Jurnal Edusains, 8(1). 98-107. Bandung: UPI.

Fazira, Suryanti, Ferazona. (2019). Analisis Higher Order Thingking Skills (HOTS) Siswa Kelas XI pada Materi Sistem Pernapasan SMAN Plus Provinsi Riau Tahun Ajaran. Jurnal Pelita Pendidikan, 7(4), 144-152. 
Haryati, R. (2012). Peningkatkan Kualitas Pembelajaran Pendidikan Kewarganegaraan Melalui Praktik Belajar Kewarganegaraan (Project Citizen). Jurnal Ilmiah CIVIS, 2(2).

Noma, Prayitno, Suwarno. (2016). PBL Untuk Meningkatkan Kemampuan Berpikir Tingkat Tinggi Siswa Kelas X SMA. Jurnal Bioedukasi, 9(2). 62-66.

Permatasari, V. (2013). Efektivitas Pendekatan Pembelajaran Open-Ended terhadap Kemampuan berpikir Matematis Peserta didik pada Materi Trigonometri Ditinjau dari Kreativitas Belajar Matematika Peserta didik. Pendidikan Matematika Solusi. Tersedia di https://core,ac,uk/download/pdf/12347888.pdf. Pada tanggal 26 Desember 2020, 18.00 WIB. 1 (1): 1-7

Putri, Ahda, dan Rahmawati. (2018). Analisis Aspek Kemampuan Berpikir Tingkat Tinggi pada Instrumen Penilaian Materi Protista untuk Peserta Didik SMA Kelas X. Jurnal Biodik, 4(1). 8-17.

Silitonga, S. (2018). Kemampuan Berpikir Tingkat Tinggi Siswa Kelas XI PMIA MAN Tanjung Morawa pada Pembelajaran Sel dengan Model PBL Berbantuan LKS. Jurnal UNM, 2 (1): 361-371.

Sugiyono. 2012. Statistika Untuk Penelitian. Bandung: Alfabeta.

Yulianis., Maharani.D.W., Susanti.S. (2019). Analisis Kemampuan Berpikir Tingkat Tinggi pada Materi Sistem Pertahanan Tubuh Siswa Kelas XI SMA. Jurnal Bioconcetta, 5(2). 105-112.

Yuliati dan Martuti. (2015). Efektivitas Penerapan Metode Field Trip untuk Meningkatkan Hasil Belajar dan Kepedulian Siswa terhadap Lingkungan. Jurnal Pendidikan Matematika dan Sains, 3(1): 39-47. 